\title{
Prisoners' Round: Examining the Literature on Recreation and Exercise in Correctional Facilities
}

\author{
Mallory A. Ambrose ${ }^{1}$ and Jeffrey W. Rosky ${ }^{2, *}$ \\ ${ }^{1}$ Department of Criminology, College of Behavioral \& Community Sciences, University of South Florida, \\ Tampa, FL 33620, USA \\ ${ }^{2}$ Department of Criminal Justice, College of Health \& Public Affairs, University of Central Florida, Orlando, FL \\ 32816, USA
}

\begin{abstract}
Opposition to correctional recreation programs expresses safety concerns for staff and argues that removal of these programs enhances the retributive nature of prison and jail. Supporters cite the health benefits for inmates and incentive for better behavior within correctional facilities. Using academic sources and media articles, we found that the available empirical data support the use of these programs. However, public perception appears yet to be swayed by such evidence. Despite this opposition, we recommend that use of physical recreation and exercise programs in correctional facilities should continue to be used within a prescribed rewards system.
\end{abstract}

Keywords: Correctional treatment, inmate exercise, prisoner rehabilitation.

\section{INTRODUCTION}

As a result of changing political climate and public sentiment, some correctional institutions across the country have reduced or eliminated altogether the availability of exercise equipment and the like from their facilities, in order to "make prison life so minimal that criminals think twice about committing crimes" (Curriden, 1995, p. 73). For example, in efforts to make jail "less comfortable" for inmates, Sheriff Judd of Polk County, Florida, has successfully ordered the removal of all basketball equipment from the jails under his authority (Myers Palm, 2010). Florida law requires correctional institutions provide exercise opportunities, but Judd cited other forms of recreation, such as jogging and stretching, that are still available following the removal of basketball equipment. This political and public shift toward more conservative ideals and policies began in the late 1980 s and early to mid1990s. The "get tough on crime" sentiment arose and policies directly addressing correctional facilities and the inmates housed within came under political and public scrutiny, with the notion of retributive justice and punishment prevailing during this time. According to this philosophy, the conditions that inmates experience must be so harsh in order to deter prisoners from wanting to return (Williams, Walker, \& Strean, 2005). The American public showed fervent support of retributive justice and punishment, holding the belief that once they are convicted, criminals forfeit their

*Address correspondence to this author at the Department of Criminal Justice, College of Health \& Public Affairs, University of Central Florida, HPA1-317, Orlando, FL 32816, USA; Tel: 407-823-3739; Fax: 407-823-5360;

E-mail: jrosky@ucf.edu rights, with polls showing that many citizens believed recreation and leisure programs to be an "expensive perk" that should not be available to inmates, especially considering that many ordinary citizens could not afford such luxuries (Carter \& Russell, 2005; Curriden, 1995). Indeed, this desired punitiveness of prison life is exemplified in Gustav Dore's 1872 woodcut (Figure 1) of Newgate Prison's yard depicting inmates walking in a circle called "prisoners' round," which served as their only form of exercise.

In response to pressure from their constituents, political officials began addressing the issue of recreation availability in the country's correctional facilities (Nossiter, 1994). In efforts to make prisons a place people did not wish to be and more like Dore's "prisoners' round," elected officials began suggesting and implementing policies that took away the availability of exercise equipment and training in various jails and prisons across the country, regardless of whether or not such policies were in violation of inmates' rights (Nossiter, 1994; Curriden, 1995). Political officials claimed to act out of concern for prison safety, as evidenced by James Fotis, executive director of the Law Enforcement Alliance of America, stating, "Free weights create a bigger, badder criminal...There are dozens of examples of guards being injured or killed by bulked-up inmates using exercise equipment as weapons" (Curriden, 1995, p. 74).

The truth, however, is that such officials were merely responding to public pressures to make prisons more punitive. Thus, in the early 1990s, Mississippi and Wisconsin were the first states to actively enforce the removal of weight lifting equipment from access by 
inmates in state correctional facilities, with many other states, including the Carolinas, Tennessee, and Ohio, seriously considering doing the same (Curriden, 1995).

In 1996, the Florida legislature entertained a bill entitled the Prison Safety Act. The legislation proposed removing weight lifting equipment, free weights, and weight machines from Florida correctional institutions, arguing that such equipment could be used as weapons and only serve to enhance the strength of known criminals. Such equipment would then be donated to school districts or charities throughout the state (Griffin, 1996). With such actions being taken at the state level, national politicians were soon under pressure to take action. Perhaps the most notable step taken at the national level came as an amendment to the 1994 Violent Crime Control and Law Enforcement Act, known as the No Frills Prison Act (Curriden, 1995; H.R. 307, 1999). The goal of this act was to ensure that living conditions within prisons were no more luxurious than the lifestyle of the average American citizen, which included the prohibition of instructional classes

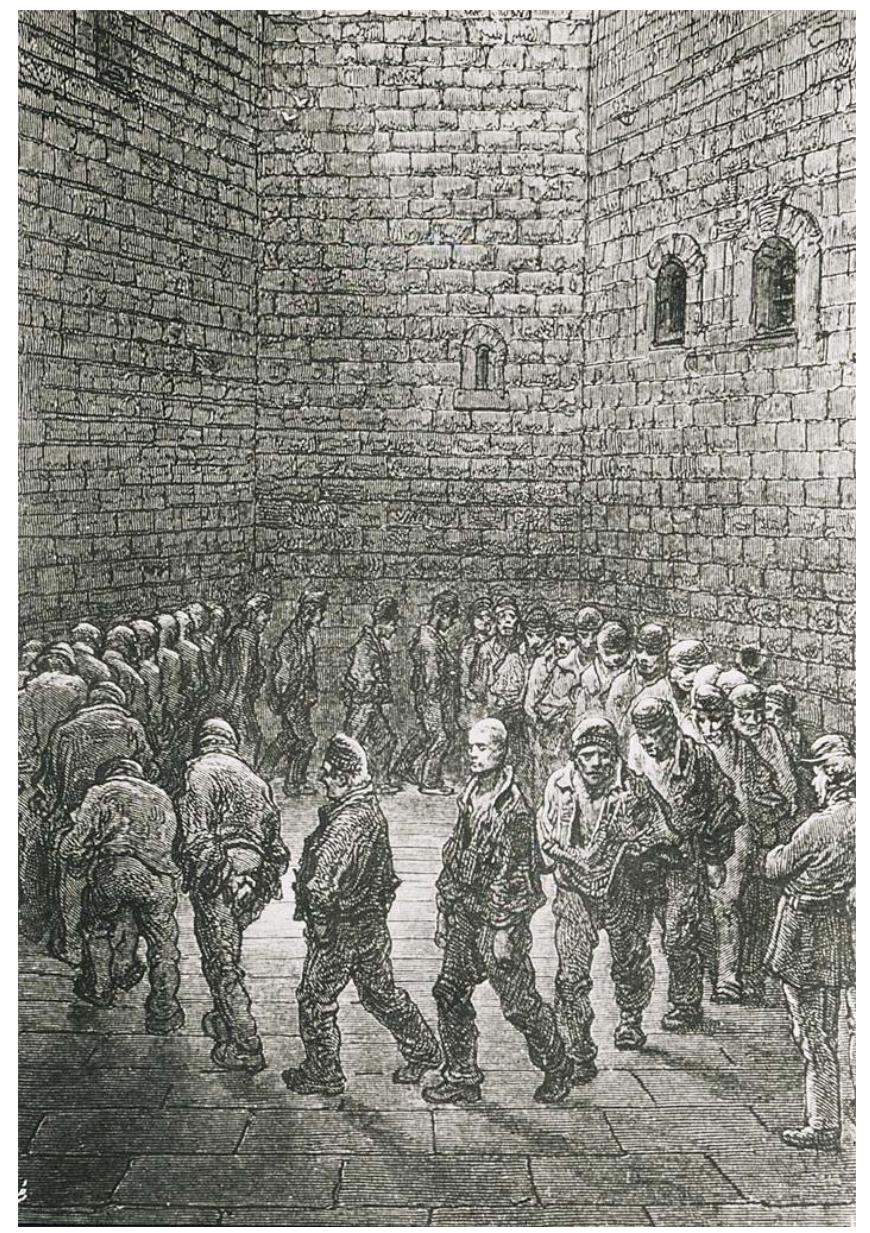

Figure 1: London, a pilgrimage: Newgate Prison (Dore, 1872). and equipment for any type of martial arts or weight lifting activities (H.R. 307, 1999). Also stipulated in the No Frills Prison Act was the allocation of prison construction funds. Money for the construction of prisons was only to be given to states that banned prison luxuries, including weight lifting equipment (Curriden, 1995). By 1997, a survey of over six hundred prison wardens indicated that a total of thirty six activities available to inmates, exercise being one of them, had been reduced or completely eliminated (Johnson, Bennett, \& Flannagan, 1997). In light of such state and national policies and pressures, it is understandable that policymakers and prison administrators would consider the removal of exercise equipment and programs from their facilities to be in compliance with public pressures and in order to continue to receive federal funds.

\section{WHY REMOVE EQUIPMENT?}

Aside from pressure to appease the public, there are a number of claims and concerns that warrant the removal of exercise equipment from correctional facilities. There has been some indication, through selfreport from incarcerated offenders, that the leisure activities that are most often employed tend to be passive, such as watching television, as opposed to active, which would include the use of exercise equipment (Frey \& Delaney, 1996). This finding indicates that it is more important to provide inmates with passive leisure activity materials, such as televisions, playing cards, and board games. It does not make sense at an administrative level to spend a significant amount of money on expensive exercise equipment if only a small number of inmates in the facility will make use of it. Another compelling argument for removing exercise equipment from jails and prisons is the evolution of certain community-specific strains of staph infections (MRSA). Inmate populations are one such community of individuals that have seen an increase in MRSA cases. The most common forms of MRSA transmission is skin-to-skin contact and the sharing of items, both of which are apt to occur with the use of exercise equipment (Federal Bureau of Prisons, 2011). An outbreak of MRSA in a correctional facility would require significant manpower and funds in order to be eradicated. It is not unreasonable for administrators of such facilities to want to remove athletic equipment from their facilities in order to prevent any such outbreaks.

In addition to the reasons to remove exercise equipment from correctional facilities, a number of 
disadvantages have been identified in relation to the presence of strength training in prison settings, which further the argument that exercise equipment should have no place in such facilities (Amtmann, Barryman, \& Fisher, 2003). First, the use of such equipment will result in larger and stronger inmates that may be better able to overpower other inmates and prison staff members. Also, the equipment in a prison has potential of being utilized as a weapon to injure other inmates or staff or as a tool to help inmates escape from the facility. Other disadvantages are strictly monetary. The public, for one, has shown disdain for the fact that their tax dollars are used to purchase exercise equipment for inmates. Also, there is a high risk for injuries to inmates if they demonstrate improper use of the equipment and, as a result, more tax dollars would be used for the medical treatment of any inmates who injure themselves while participating in the use of the facility's exercise equipment. Finally, there is the simple fact that exercise equipment is fairly expensive to buy and maintain, which is money that could be put to better use elsewhere in the facility. (Amtmann, Barryman, \& Fisher, 2003).

\section{WHY KEEP EQUIPMENT?}

However, it is important to consider the evidence of the opposing view, that exercise equipment should not be removed from correctional facilities. While containing inmates physically is necessary to maintain prison order, it alone is not sufficient. Life in a correctional facility is highly stressful and overcrowded and many inmates suffer from psychological conditions, including depression and anxiety. In facilities where these issues are prominent, the inmates are more likely to commit suicide, homicide, or assault, and suffer from various medical and psychological illnesses (Zimring, Munyon, \& Ard, 1988). Additionally, Fazel and Danesh found that one in every seven inmates meet the criteria for diagnosis of major depressive disorder (2002).

As a result of the prominence of psychological disorders in the inmate population, much of the existing research on the issue of exercise in prisons addresses the psychological benefits of exercise and recreation and the positive outcomes of such benefits on the prison environment. One such study, investigating the effects of weight lifting on the psychological health of those who practice it, found substantial measured reductions in the frequency and severity of verbal aggression, hostility, and anger (Wagner, McBride, \& Crouse, 1999). Similarly, regular weight lifting increases inmates' self-confidence and social skills by reducing tension levels (Buckaloo, Krug, \& Nelson, 2009; Byrd, 1963; Hilyer \& Mitchell, 1979; Melnick \& Mookerjee, 1991). These studies indicate that a major role of exercise in correctional facilities is as an outlet or coping mechanism to deal with the stresses of prison or jail life (Cooper \& Berwick, 2001).

Exercise has been shown to induce a sense of calmness for the individuals who regularly partake in exercise regimens (Buckaloo, Krug, \& Nelson, 2009). In a study by Wagner, McBride, and Crouse (1999), researchers found that a group of inmates who participated in regular weight-training indicated significantly lower levels of aggression variables, increased morale, and were careful not to break any prison rules so as not to lose access to exercise equipment as compared to a non-weight-training control group. Inmates who participated in this study admitted that lifting weights did, in fact, provide them with a release from the stressors of life in prison. Applying these findings to correctional facilities, allowing inmates access to exercise equipment on a regular basis may very well reduce the frequency of misconduct, which could arguably improve the prison setting not only for the inmates but for the staff as well.

Other benefits of regular exercise and recreation include, but are not limited to, the development of legitimate stress relievers, self-esteem boosts, identification of personal needs and acceptable means of addressing them, and the development of new interests (Robertson, 2000). Regular physical activity has been shown to reduce psychosocial stress, reduce rates of depression, and can even be a helpful part of treatment for individuals struggling with substance abuse (Williams, Walker, \& Strean, 2005). These personal changes that may occur within inmates with regular access to exercise benefit not only the inmates but the society as a whole by reducing the likelihood of future criminal behavior. Thus, the therapeutic qualities of recreation and exercise foster personal development and potentially reduce the occurrence of harmful behavior (Carter \& Russell, 2005).

Considering that some individuals may not care about the personal and psychological benefits awarded to inmates who actively participate in exercise regimens, it may be more persuasive to point out the role of exercise equipment as an incentive and tool for behavior management within correctional facilities. When approached with questions regarding the importance of exercise equipment in their facilities, correctional staff and inmates alike hold that such 
amenities are a mechanism for prison management; making exercise equipment available to inmates keeps them occupied with something productive, which reduces the time available for them to participate in illicit activities, and can also be used as part of a reward system for good behavior (Amtmann, Barryman, \& Fisher, 2003; Applegate, 2001; BraxtonMintz, 2009). In this regard, access to exercise equipment and recreational activities can be employed by correctional facilities as a tool to encourage positive behavior and, in efforts to punish inmates for poor behavior, access to such luxuries can be revoked. In the same vein, providing inmates regular access to exercise limits the time they may engage in negative behavior, resulting in a safer working environment for correctional staff (Braxton-Mintz, 2009). These practices have proven effective in a number of institutions and it can be argued that removing exercise equipment would make prisons more dangerous, as another controlling mechanism would be unavailable (Griffin, 1996).

\section{THE COSTS AND BENEFITS}

Having considered the evidence for and against the removal of exercise equipment from prisons and jails, it is important to identify the potential costs and benefits of each side before deciding which action to take. Costs and benefits, as they apply to this argument, are at the facility, inmate, and societal levels. Implementation of this policy, removing exercise equipment from correctional facilities, has a variety of potential monetary costs and benefits to both the facilities and society. Without exercise equipment in the facilities, it may be more likely that inmates will exhibit physical and psychological health issues that will require medical treatment. If higher numbers of individuals require medical treatment, there will be an increase in money, typically from tax dollars, spent on treating the inmates (Amtmann, Barryman, \& Fisher, 2003). It has also been found that implementing exercise programs is cheaper than a facility having to pay for items broken or damaged as a result of prison misconduct, which is reduced when inmates partake in regular exercise (Braxton-Mintz, 2009). Money may also be saved in terms of manpower: one study has shown that less supervision of inmates is required when they are engaged in exercise activities (Amtmann, Barryman, \& Fisher, 2003). In terms of the policy's monetary benefits, on the other hand, facilities are likely to save a considerable amount of money if they get rid of exercise equipment because expensive new equipment will not have to be purchased to replace broken equipment and the facility will not have to set aside money for equipment maintenance (Amtmann, Barryman, \& Fisher, 2003). Also, individual citizens are likely to be pleased with such a policy if they feel their tax dollars should not be used to provide criminals with certain luxuries.

Other costs and benefits relate mostly to psychological phenomena. The research indicates minimal benefits, in terms of psychology, for banning exercise equipment from correctional facilities. The main benefit is that facility staff members, who feel threatened or afraid of more muscular inmates, will possibly feel safer and more in control while on the job because inmates would not be able to work out and increase their size (Amtmann, Barryman \& Fisher, 2003). The costs in this case greatly outnumber the benefits. The availability of regular exercise and recreation improves the mental and physical health of

Table 1: Peer-Reviewed Publications Examining Perceptions of Inmate Exercise Programs

\begin{tabular}{|c|c|c|c|}
\hline Source & Measures & Sample & Result \\
\hline $\begin{array}{l}\text { Applegate, } \\
2001\end{array}$ & $\begin{array}{c}\text { Public opinions regarding amenities in } \\
\text { jails/prisons }\end{array}$ & $\begin{array}{l}200 \text { Central Florida } \\
\text { Residents }\end{array}$ & $\begin{array}{l}\sim 50 \% \text { favored elimination of } \\
\text { recreation/entertainment amenities }\end{array}$ \\
\hline FDOC, 1998 & $\begin{array}{l}\text { Public opinions regarding Florida prisoner } \\
\text { access to weights }\end{array}$ & $\begin{array}{l}854 \text { General Public; } \\
346 \text { News media; } \\
656 \text { Dept. of } \\
\text { Corrections staff }\end{array}$ & $\begin{array}{l}\text { General Public-48.8\% approval } \\
\text { News media }-64.7 \% \text { approval } \\
\text { DOC staff- } 50.6 \% \text { approval }\end{array}$ \\
\hline $\begin{array}{l}\text { Johnson, } \\
\text { Bennett \& } \\
\text { Flannagan, } \\
\quad 1995\end{array}$ & $\begin{array}{l}\text { Correctional administration assessments } \\
\text { regarding importance of prison } \\
\text { services/programs }\end{array}$ & $\begin{array}{l}\text { NCES } 95 \text { results; } \\
829 \text { state wardens }\end{array}$ & $32 \%$ favored eliminating weight lifting \\
\hline $\begin{array}{c}\text { Pawelko \& } \\
\text { Anderson, } 2005\end{array}$ & $\begin{array}{c}\text { Attitudes toward correctional recreation: } \\
\text { National Correctional Recreational } \\
\text { Association; National Recreation\& Park } \\
\text { Association }\end{array}$ & $\begin{array}{l}167 \text { members filled } \\
\text { out questionnaires }\end{array}$ & $\begin{array}{c}\text { NPRA favors more punishment/retribution; NCRA: } \\
\text { pro rehab, more support for correctional } \\
\text { recreation/weightlifting }\end{array}$ \\
\hline
\end{tabular}


inmates and, therefore, removing their access to exercise equipment may result in a steep decline in the mental and physical health of inmates (Williams, Walker, \& Strean, 2005). As previously discussed, exercise provides inmates with a productive way of coping with and managing stress and increases social interaction, which can aid the offender in contributing to society upon release. Without the development of such coping and managing strategies, inmates are at greater risk for recidivating and posing a threat to society (Buckaloo, Krug, \& Nelson, 2009). However, if inmates are able to develop a regular exercise routine that they bring with them to the outside world upon release, criminals will have less leisure time, which will decrease the likelihood of engaging in criminal behavior and improve their ability to interact socially in a positive manner (Buckaloo, Krug, \& Nelson, 2009; Carter \& Russell, 2005). This being the case, it is likely that the public will not protest the existence of prisoner recreational amenities, as people are generally accepting toward retaining amenities that are useful for the management of inmates or for the rehabilitation of offenders (Applegate, 2001).

\section{EXAMINING THE LITERATURE}

Having examined the arguments for and against exercise and recreation programs, how does it fit together into a coherent picture? Table 1 outlines the academic literature regarding perceptions of exercise programs for inmates. This literature expresses both the public's negative perceptions toward the issue and correctional organizations' positive perceptions. Applegate (2001) found that roughly half of the Florida residents that were questioned favored eliminating all recreational amenities, and any others that provide entertainment, from correctional institutions. The public opinion survey conducted by the Florida Department of Corrections (1998) found that a majority of the general public disapproves of prisoners' access to weights, while the majority of both news professionals and department of corrections staff approve. Johnson, Bennett, and Flannagan (1995) assessed the opinions of corrections administrators regarding various prison services and programs. Of the 829 state wardens interviewed, only $32 \%$ showed favor toward eliminating weight lifting. Pawelko and Anderson (2005) issued 167 questionnaires to members of both the National Correctional Recreation Association (NCRA) and the National Recreation and Park Association (NRPA). The findings indicate that NRPA members favored the removal of weight lifting from correctional facilities, in keeping with the organization's inclination toward punishment and retribution, while NCRA members, who tend to be pro-rehabilitation, showed more support for correctional, recreation and weight lifting.

Next, Table 2 addresses public opinion and media coverage of correctional recreation and exercise programs. Here, the literature is grouped according to the overall theme of each piece: whether the perceptions regarding correctional recreation and exercise are positive or negative. The Associated Press (2002) reports on the state of correctional recreation in Florida, where sporting equipment was to be reintroduced into facilities, a move supported by the Department of Corrections workers. These individuals expressed concern for unstructured inmate time, welcoming the equipment as a means to keep inmates busy. Articles by both Braxton-Mintz (2009) and Fuchs (2003) stress the benefits of using recreation and exercise as privileges to be earned and taken away in order to better manage inmate behavior and motivate them toward behaving in a positive manner. BraxtonMintz (2009) goes on to suggest that implementing such programs may ultimately save the facility money that would be spent on fixing items broken by idle inmates with no outlet for aggression or boredom. Carter and Russell (2005) interviewed and surveyed prison administrators, staff, and inmates to gauge their perceptions of the effectiveness of recreation programs. All groups in question were in favor of such programs and identified them as being congruent to the overall goals of the facility. Dallao (1996) notes the benefits of recreation on recidivism. Such programs allow inmates to relieve tension and encourage them to develop new skills and interests that they may bring with them upon release to help keep them out of trouble. LeDuff's article (2003) centers on the sentiments toward sports programs at San Quentin, finding that facility employees and inmates see the programs as a way to better the individual and benefit society. Robertson (2000) specifically addressed the benefits of recreation on incarcerated youth, stating that it goes a long way toward improving their mental, physical, social, emotional, and spiritual well-being. Williams, Walker, and Strean (2005) conclude in their article that, while the benefits of recreation and exercise in correctional facilities needs more empirical evidence, the programs should not be eliminated.

The Associated Press (2003) reports on a piece of Florida legislation that allowed exercise equipment back into the state's correctional facilities. The article focuses on those opposed to the law, citing then-state attorney general and future governor Charlie Crist as 
Table 2: News \& Online Articles Regarding Benefit/Perceptions of Inmate Exercise Programs

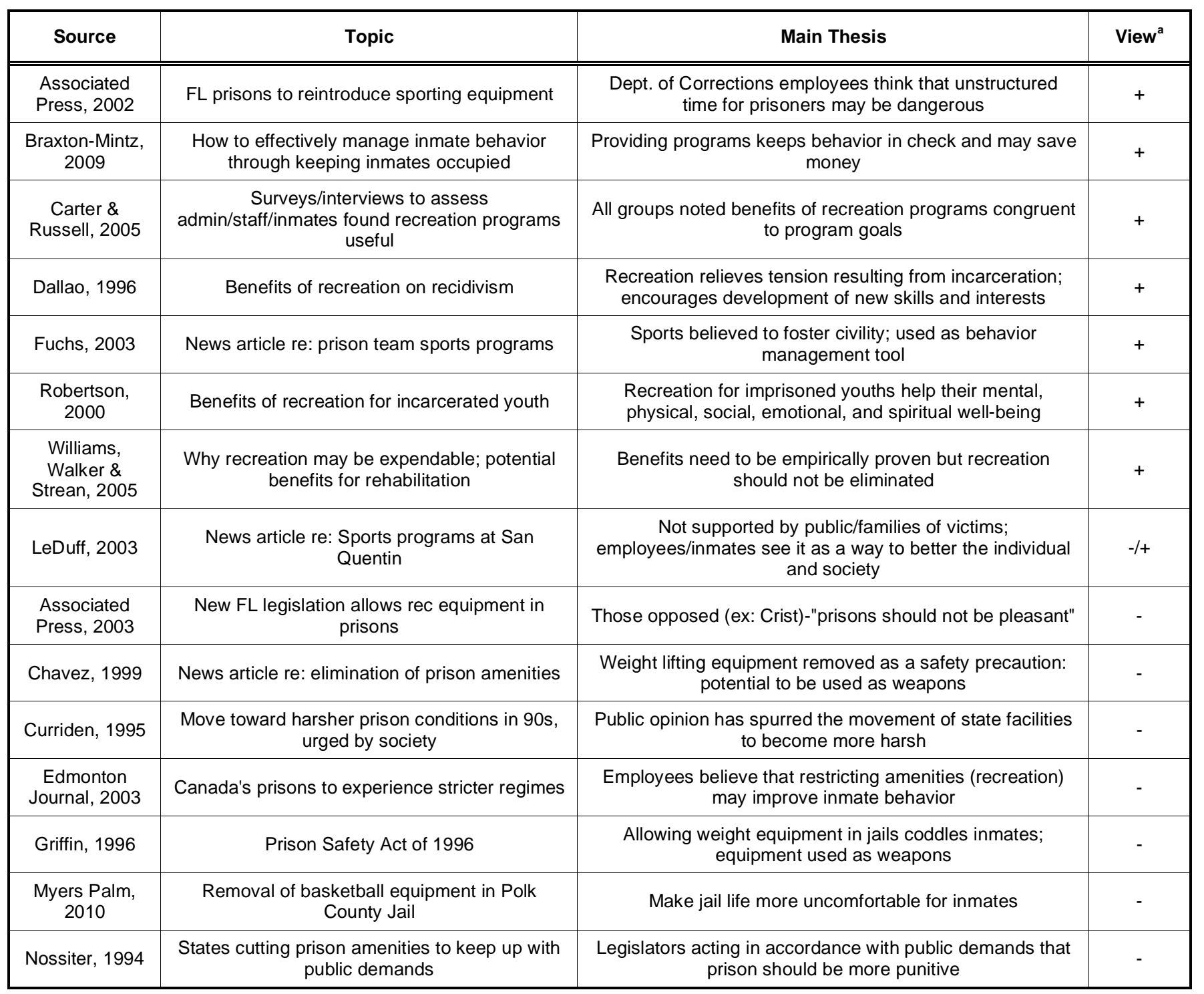

${ }^{a}+=$ positive view; -=negative view.

an advocate against prisons being pleasant places for the inmates. Chavez (1999) addresses the issue of eliminating prison amenities, including recreation and exercise equipment, as a safety precaution. It is posited that such equipment may be used as weapons against both other inmates and staff members. Curriden (1995) and Nossiter (1994) found that the move toward harsher prison conditions in the 1990s was spurred by public opinion that prisons and jails should not be places of leisure. The Edmonton Journal (2003) provides an international opinion, writing about more harsh conditions in Canadian prisons in hopes of improving inmate behavior through restricting available amenities. Griffin (1996) writes regarding the Prison Safety Act of 1996, a piece of legislation that pushed for the removal of gym equipment from correctional facilities. Supporters of the Act claim that allowing such amenities coddles the inmates and provides them with weapons to use against others. LeDuff (2003), discussed above, also expressed that the sports programs at San Quentin were not supported by the general public, especially families of victims, who wanted the inmates to suffer, not play games.

Lastly, Table 3 outlines the academic literature regarding the benefits of exercise programs in correctional facilities. Bishop and Merton (2011) studied a population of 261 inmates in Oklahoma to assess the risk of comorbid health issues among older male inmates. They found that participation in physical activity decreased the chances of comorbid health impairment by $44 \%$. Another study conducted using Oklahoma inmates, Buckaloo, Krug, and Nelson 
Table 3: Peer-Reviewed Publications Examining the Benefits/Perceptions of Inmate Exercise Programs

\begin{tabular}{|c|c|c|c|}
\hline Source & Measures & Sample & Findings \\
\hline $\begin{array}{c}\text { Bishop \& Merten, } \\
2011\end{array}$ & $\begin{array}{c}\text { Risk of comorbid health impairment among } \\
\text { older male inmates }\end{array}$ & $\begin{array}{l}261 \text { Oklahoma male } \\
\text { inmates age } 45-82\end{array}$ & $\begin{array}{l}\text { Physical activity reduced the odds of } \\
\text { comorbid health impairment by } 44 \%\end{array}$ \\
\hline $\begin{array}{l}\text { Buckaloo, Krug \& } \\
\text { Nelson, } 2009\end{array}$ & $\begin{array}{l}\text { Effect of exercise on inmates' psychological } \\
\text { health; used Beck Depression Inventory II }\end{array}$ & $\begin{array}{l}60 \text { Oklahoma Dept. } \\
\text { of Corrections } \\
\text { Inmates }\end{array}$ & $\begin{array}{l}\text { Exercise results in lower depression/anxiety } \\
\text { and more positive life experiences }\end{array}$ \\
\hline $\begin{array}{l}\text { Hensley, } \\
\text { Koscheski \& } \\
\text { Tewksbury, } \\
\text { (2003) }\end{array}$ & $\begin{array}{l}\text { Attitudes of college students in regards to } \\
\text { prison amenities }\end{array}$ & 553 college students & $\begin{array}{c}\text { Voted to remove "frills" items and keep } \\
\text { rehabilitative items }\end{array}$ \\
\hline $\begin{array}{l}\text { Hensley, Miller, } \\
\text { Tewksbury \& } \\
\text { Koscheski, } 2003\end{array}$ & $\begin{array}{l}\text { Attitudes toward inmate amenities of criminal } \\
\text { justice majors versus non-majors }\end{array}$ & 570 college students & $\begin{array}{l}\text { No significant differences among two } \\
\text { groups; support for counseling and } \\
\text { educational programs }\end{array}$ \\
\hline $\begin{array}{c}\text { Hensley, } \\
\text { Koscheski \& } \\
\text { Tewksbury, 2007 }\end{array}$ & $\begin{array}{l}\text { Attitudes toward inmate amenities of } \\
\text { criminology majors versus non-majors }\end{array}$ & $\begin{array}{l}553 \text { college students } \\
\text { (14.3\% criminology } \\
\text { majors })\end{array}$ & $\begin{array}{l}\text { Support highest for rehabilitative programs } \\
\text { and lowest for "comfort"-related items }\end{array}$ \\
\hline Lenz, 2002 & $\begin{array}{l}\text { Degree of public approval of inmate amenities } \\
\text { based on perceptions of who funds such } \\
\text { amenities }\end{array}$ & $\begin{array}{l}180 \text { members of the } \\
\text { general public }\end{array}$ & $\begin{array}{c}\text { Citizens support some prison amenities until } \\
\text { they are informed that taxpayer dollars fund } \\
\text { the programs }\end{array}$ \\
\hline $\begin{array}{l}\text { Perez-Moreno et } \\
\quad \text { al. } 2007\end{array}$ & $\begin{array}{c}\text { Effect of exercise (4 months) on physiology } \\
\text { and quality of life (QOL) of HIV infected } \\
\text { Spanish inmates }\end{array}$ & 27 male inmates & Significant QOL increase in treatment group \\
\hline $\begin{array}{l}\text { Tewksbury \& } \\
\text { Mustaine, } 2005\end{array}$ & $\begin{array}{c}\text { Attitudes and perceptions of correctional staff } \\
\text { regarding which amenities should be available } \\
\text { to inmates }\end{array}$ & $\begin{array}{l}554 \text { Kentucky Dept. } \\
\text { of Corrections staff }\end{array}$ & Overall, favorable views on most amenities \\
\hline $\begin{array}{l}\text { Wagner, McBride } \\
\text { \& Crouse, } 1999\end{array}$ & Effects of weight training on aggression levels & $\begin{array}{l}240 \text { adult male Texas } \\
\text { inmates; } 202 \\
\text { completed }\end{array}$ & $\begin{array}{c}\text { Aggression, anger, hostility all decreased in } \\
\text { treatment group }\end{array}$ \\
\hline
\end{tabular}

(2009), used the Beck Depression Inventory II to determine the effect of exercise of inmates' psychological health. Using a population of sixty inmates, the authors found that participation in exercise led to lower scores of depression and anxiety and more positive life experiences. In 2003, Hensley, Koscheski, and Tewksbury investigated the attitudes of college students in regards to inmates' access to amenities. They found the students voted to remove only those amenities identified as "frills" and showed favor toward rehabilitative efforts. The authors suggest that correctional facilities have been cutting back because of issues with money and staffing, along with misguided political beliefs, rather than authentic public sentiment. Hensley, Miller, Tewksbury, and Koscheski (2003) examined the attitudes of criminal justice majors in relation to non-majors in regards to attitudes toward inmates' access to psychological counseling, education programs, television, cigarettes, weight lifting, and conjugal visits. Authors found no statistically significant differences among the groups, as both majors and nonmajors showed more support for counseling and education programs and less support for the luxuries. In a similar study, Hensley, Koscheski, and Tewksbury (2007) compared attitudes toward inmate amenities of criminology majors versus non-majors. Rehabilitative programs garnered greatest support. The two groups, criminology majors and non-majors, differed considerably on only two issues: majors greatly favored providing legal assistance and condoms to inmates.

Lenz (2002) administered three different surveys to the general public to gauge public support for prison amenities based on funding. One survey informed participants that inmates paid for amenities themselves, another claimed that amenities were funded with taxpayers dollars, while the third survey made no mention of amenity funding. Lenz (2002) found that respondents to the first survey were more likely to support access to most amenities and respondents to the third survey closely resembled the responses of the first survey. The researcher concludes that people generally support some prison amenities until being informed that such amenities are funded by taxpayer dollars. Pérez-Moreno, et al. (2005) studied twenty-seven, HIV-positive, Spanish male inmates to examine the effect of four months of exercise on their physiology and quality of life. The findings indicate a significant increase in quality of life for the treatment group. Tewksbury and Mustaine 
(2005) surveyed 554 correctional staff of Kentucky prisons to find that a majority favored eliminating boxing/martial arts, conjugal visits, pornography, condoms, R-rated movies, and cable television. $90 \%$ of respondents voted to maintain counseling, books, phone calls, air conditioning, educational programs, and some amenities of mild entertainment, such as radio, basic television, and magazines. Finally, Wagner, McBride, and Crouse (1999) investigated the effect that weight training has on levels of aggression, using adult male inmates in Texas. This study yielded results that indicate a decrease in aggression, anger, and hostility in the treatment group.

Lastly, there are multiple limitations regarding the works cited above. Most of the peer-reviewed literature data were from nonrandom sampling and limited to a specific cohort or group that may not truly represent the nature of opinions and cost and benefits of prison exercise. Additionally, news accounts may reflect certain political and publication biases of the media outlets publishing the material and cannot be considered representative of overall sentiment regarding prison exercise of the general public, local, state, and federal policymakers, and correctional staff. Hence, the results presented here should be taken with a healthy grain of skepticism and viewed with some discretion.

\section{CONCLUSIONS}

Given the above limited evidence for and against, including the costs and benefits, of a policy that would effectively remove all exercise equipment from a correctional facility, certain recommendations can now be put forth. It is ultimately in the best interest of both the inmate population and the correctional staff to not implement such a policy, as prison experts report that doing so is "less likely to deter crime than to make inmates angry and harder to handle" (Nossiter, 1994). Research has shown that regular exercise greatly improves the mentality of inmates, keeps them actively involved in a productive manner, and reduces the time available for inmates to break the rules. Also, inmates are less likely to engage in negative or risky behaviors if access to exercise equipment is used as part of a reward system: inmates value access to such amenities and are thus more likely to abide by the rules in order that they may keep such privileges. These effects on inmate mentality and behavior create a more pleasant and safer working environment for correctional officers, as they will encounter violence and aggression from inmates on a more infrequent basis.
Exercise equipment will be most useful in a correctional facility when it is used as part of a reward system. Doing so will produce the desired behaviors in inmates and allows the staff to enforce punishment, when necessary, that actually has an effect on the inmates. The evidence shows that inmates highly value access to exercise equipment and are careful not to act out so that they will not lose their privileges. If a facility is to keep exercise equipment, it is suggested that the facility invest in providing educational classes to inform inmates of proper equipment use to cut down on safety issues. Although this may, at first, increase the facility's costs, it will help cut down on injuries requiring medical attention, which will save the facility, and the tax payers, money in the long run. Teaching inmates how to safely and effectively use exercise equipment will not only reduce injuries but will likely result in greater overall health of the inmate population.

Facility managers often cite public unhappiness with inmate luxuries as a reason for proposing the removal of exercise equipment. However, there exists little to no empirical evidence of the effects or severity of such sentiments. On the contrary, a study by Applegate (2001), found that citizens are willing to support prison amenities if they are useful in managing the facility or aid in the rehabilitation of offenders. As a result of this finding, it would benefit correctional facilities to demonstrate to the public that exercise equipment and activities are of such use to the prison and the inmates. In so doing, the facility is likely to gain support from the public, as long as exercise programs do not give the inmates an appearance of having a significant advantage in quality of life over law-abiding citizens.

Finally, while more empirical research needs to be done, including examining the effects of exercise equipment with institutional misconduct and recidivism measures and cost/benefit analyses, the accumulated but limited evidence thus far shows that, despite public and political pressures, it is likely in the best interest of American corrections to avoid implementing policies that would remove exercise equipment and retreat towards "prisoners' round."

\section{REFERENCES}

Amtmann, J., Barryman, D., \& Fisher, R. 2003. Weight lifting in prisons: A survey and recommendations. Journal of Correctional Health Care 10(1):109-118. http://dx.doi.org/10.1177/107834580301000109

Applegate, B. K. 2001. Penal austerity: perceived utility, desert, and public attitudes toward prison amenities. American Journal of Criminal Justice 25(2):253-268. http://dx.doi.org/10.1007/BF02886849

Associated Press. 2002, June 20. Prisons set to buy sporting goods. 
Associated Press. 2003, May 12. For first time in a decade, Florida prisons buy recreation gear.

Bishop, A. J., \& Merten, M. J. 2011. Risk of comorbid health impairment among older male inmates. Journal of Correctional Health Care 17(1):34-45. http://dx.doi.org/10.1177/1078345810385912

Braxton-Mintz, R. 2009. Inmate programs: A tool for managing behavior. Corrections Today 71(6):100-101.

Buckaloo, B. J., Krug, K. S., \& Nelson, K. B. 2009. Exercise and the low-security inmate: Changes in depression, stress, and anxiety. The Prison Journal 89(3):328-343. http://dx.doi.org/10.1177/0032885509339508

Byrd, O. 1963. A survey of beliefs and practices of psychiatrists on the relief of tension by moderate exercise. Journal of School Health 33:426-427. http://dx.doi.org/10.1111/j.1746-1561.1963.tb00436.x

Carter, M. J., \& Russell, K. J. 2005. What is the perceived worth of recreation? Results from a county jail. Corrections Today 67(3):80-91.

Chavez, E. 1999, June 6. Prison privileges are disappearing nationwide trend of limiting amenities in jail comes down to issues of economics and safety. The Morning Call.

Cooper, C., \& Berwick, S. 2001. Factors affecting psychological wellbeing of three groups of suicide-prone prisoners. Current Psychology: Developmental, Learning, Personality, Social 20:169-182. http://dx.doi.org/10.1007/s12144-001-1025-0

Curriden, M. 1995. Hard time. ABA Journal 81(7):72-75.

Dallao, M. 1996. Changing the rules of recidivism through recreation. Corrections Today 58(1):80-101.

Dore, G. 1872. London, a pilgrimage: Newgate Prison. Retrieved May 6, 2012 from ARTstor database.

Edmonton Journal. 2003, March 18. Canadian prison officers welcome proposal for stricter regime.

Fazel, S., \& Danesh, J. 2002. Serious mental disorder in 23,000 prisoners: A systematic review of 62 surveys. Lancet 359:545-550. http://dx.doi.org/10.1016/S0140-6736(02)07740-1

Federal Bureau of Prisons. 2011. Management of methicillin-resistant Staphylococcus aureus (MRSA) infections. Washington, DC: US DOJ.

Florida Department of Corrections 1998. Corrections in Florida: 1998 opinion survey. Tallahassee, FL: FL DOC.

Frey, J. H., \& Delaney, T. 1996. The role of leisure participation in prison: A report from consumers. Journal of Offender Rehabilitation 23:79-89. http://dx.doi.org/10.1300/J076v23n01 08

Fuchs, M. 2003, April 29. Baseball; learning team spirit behind bars. The New York Times.

Griffin, M. 1996, March 27. Senate weighs dismantling exercise equipment in prisons. The Sun Sentinel.

Hensley, C., Koscheski, M., \& Tewksbury, R. 2003. College students' attitudes toward inmate programs, services, and amenities. Criminal Justice Studies 16(4):295-304. http://dx.doi.org/10.1080/0888431032000183498

Hensley, C., Miller, A., Tewksbury, R., \& Koscheski, M. 2003. Student attitudes toward inmates privileges. American journal of Criminal justice 27(2):249-262. http://dx.doi.org/10.1007/BF02885697
Hensley, C., Koscheski, M., \& Tewksbury, R. 2007. Examining criminology majors' and non-majors' attitudes toward inmate programs, services, and amenities. Criminal Justice Studies 20(3):217-230.

http://dx.doi.org/10.1080/14786010701617631

Hilyer, J., \& Mitchell, W. 1979. The effect of systematic physical fitness training combined with counseling on the self-concept of college students. Journal of Counseling Psychology 26:427-436.

http://dx.doi.org/10.1037/0022-0167.26.5.427

H.R. 370 No Frills Prison Act, $106^{\text {th }}$ Cong., 1 sess. 1999.

Johnson, W.W., Bennett, K., \& Flannagan, T.J. 1997. Getting tough on prisoners: Results from the National Corrections Executive Survey. 1995. Crime and Delinquency 43:24-41. http://dx.doi.org/10.1177/0011128797043001002

LeDuff, C. 2003, May 19. Those are definitely not angels in the outfield. The New York Times.

Lenz, N. 2012. "Luxuries" in prison: The relationship between amenity funding and police support. Crime and Delinquency 48(4):499-525. http://dx.doi.org/10.1177/001112802237127

Melnick, M., \& Mookerjee, S. 1991. Effects of advanced weight training on body-cathexis and self-esteem. Perceptual and Motor Skills 72:1335-1345. http://dx.doi.org/10.2466/pms.1991.72.3c.1335

Myers Palm, A. 2010, December 23. Polk Sheriff removes basketball from jail, donates equipment to churches. The Orlando Sentinel.

Nossiter, A. 1994, September 17. Making hard time harder, states cut jail TV and sports. The New York Times.

Pawelko, K.A., \& Anderson, T.K. 2005.Correctional recreation, weight lifting in prison, and rehabilitation: A comparison of attitudes. Canadian Association for Leisure Studies.

Pérez-Moreno, F., Cámara-Sánchez, M., Tremblay, J. F., RieraRubio, V. J., Gil-Paisán, L., \& Lucia, A. 2007. Benefits of exercise training in Spanish prison inmates. International Journal of Sports Medicine 28:1046-1052. http://dx.doi.org/10.1055/s-2007-965129

Robertson, B.J. 2000. Leisure education as a rehabilitative tool for youth in incarceration settings. Journal of Leisurability 27(2):27-31.

Tewksbury, R., \& Mustaine, E.E. 2005. Insiders' views of prison amenities: Beliefs and perceptions of correctional staff members. Criminal Justice Review 30(2):174-188. http://dx.doi.org/10.1177/0734016805284305

Wagner, M., McBride, R. E., \& Crouse, S. F. 1999. The effects of weight-training exercise onaggression variables in adult male inmates. The Prison Journal 79(1):72-89. http://dx.doi.org/10.1177/0032885599079001005

Williams, D. J., Walker, G. J., \& Strean, W. B. 2005. Correctional recreation on death row: Should pardon be granted? Journal of Offender Rehabilitation 42(2):49-67. http://dx.doi.org/10.1300/J076v42n02 04

Zimring, C. M., Munyon, W. H., \& Ard, L. (1988). Reducing stress in jails. Ekistics 55(331/332):215-229.

\section{DOI: http://dx.doi.org/10.6000/1929-4409.2013.02.34}

(C) 2013 Ambrose and Rosky; Licensee Lifescience Global.

This is an open access article licensed under the terms of the Creative Commons Attribution Non-Commercial License (http://creativecommons.org/licenses/by-nc/3.0/) which permits unrestricted, non-commercial use, distribution and reproduction in any medium, provided the work is properly cited. 